\title{
Mechanical Performance on Slurry Infiltrated Fibre Concrete
}

\author{
Muthukannan M, Suresh Kumar A
}

\begin{abstract}
Generally concrete has low cracking resistance, low tensile strength and low ductility. To improve the tensile properties of concrete members a conventional reinforced bars are used. These provide the tensile strength of concrete members and do not increase the inherent tensile strength of concrete. It has been known that the addition of small, closely placed and uniformly dispersed fibers to concrete would act as crack arrester and improve it's static and dynamic properties. In this paper, the mechanical properties like compression strength, split tensile strength, flexural strength, flexural toughness and stress - strain characteristics of SIFCON specimens and then compared with conventional FRC and conventional concrete are investigated. The M30 grade of concrete is used for both fiber reinforced concrete and conventional concrete. The experimental program consists of investigation on the mechanical properties of SIFCON specimens with $8 \%$ fiber content and then compared with conventional SFRC with $0.5 \%, 0.75 \%$ and $1 \%$ fiber content and then compared with conventional concrete. Steel fibers with two types straight and crimped having $30 \mathrm{~mm}$ and $18 \mathrm{~mm}$ length have been investigated. The result shows that the compressive strength of SFRC is found to increase with increase in fiber content. SIFCON has higher Split tensile strength and Flexural strength than SFRC and control concrete.
\end{abstract}

Keywords:Slurryinfiltrated Concrete, SIFCON, Steel fiber reinforced concrete, crimped steel fibers

\section{INTRODUCTION}

SIFCON (Slurry Infiltrated Fiber CONcrete) was invented in 1979 by Dr.DavidLankard. A special type of fiber reinforced concrete is Slurry Infiltrated Fibrous Concrete. In two aspects it is different from normal fiber reinforced concrete. They are the production method and content of fiber. In FRC, the fiber content is less compare to SIFCON, usually in FRC, the fiber content varies from 0.5 to $2 \%$ by volume, whereas in SIFCON, the fiber content may vary between 5 and $12 \%$. Due to high fiber content the process of making SIFCON is different. In FRC, the fibers are added to the wet or dry mix of the concrete during mixing, but SIFCON is prepared by infiltrating cement slurry into a bed of preplaced fibers. Alternatively, the fibers can also be implanted into the cement sand slurry. SIFCON has been successfully used in structures subjected to blast and dynamic loading. Because of high ductility and impact resistance, the composite has excellent potential for

Revised Manuscript Received on July 22, 2019.

* Correspondence Author

Muthukannan $\mathbf{M}^{*}$, Department of Civil Engineering, Kalasalingam Academy of Research and Education, Virudhunagar, India. Email: civilkannan@gmail.com

Suresh Kumar A, Department of Civil Engineering, Kalasalingam Academy of Research and Education, Virudhunagar, India. Email: sureshalmighty@gmail.com constructing structural components which need to resist high impact force and exhibit high ductility, such as explosive storage cabinets, blast resistant doors, high security vaults and missile silo structures. It is also very effective for precast applications, where standard modes of reinforcement are ineffective.

\section{METHODOLOGY}

SIFCON is cast a pre placing technique in which fibers are placed in the mould or on a substratum and infiltrated with cement-based slurry. The fibers can be sprinkled by hand or by using fiber-dispensing units. The amount of fiber that can be incorporated depends on fiber aspect ratio, fiber geometry and placement technique.Following are the materials used for the present investigation of Fiber Reinforced Reactive Powder Concrete.

The following are the steps involved in the preparation of SIFCON specimens.

- Preparation of forms i.e. substrates.

- Placement of the steel fibers.

- Preparation of the SIFCON slurry.

- Infiltration of the slurry through the packed steel fiber bed.

- Curing.

\section{MATERIALS USED}

The following materials have been used for the development of SIFCON and their properties have been presented in the following paragraphs.

- Cement

- Fine aggregate

- Coarse aggregate

- Chemical admixtures

- Water

- Steel fibers

\section{A. Cement}

In the present investigation, OPC of 53 grade was used and the cement sample was tested as per IS: 4031-1968 to obtain the following properties:

- Specific gravity (determined by Le - Chatelier flask) (IS: 1727-1967)

- $\quad$ Standard consistency (IS: 4031 - 1968 Part 4)

- Initial setting time (IS: 4031 - 1968 Part 4)

- $\quad$ Final setting time (IS: 4031 - 1968 Part 4)

The test results on cement sample are listed in Table 1 . 
Table-I: Physical Properties of Cement

\begin{tabular}{|c|c|c|c|}
\hline \multicolumn{2}{|c|}{ Physical properties } & $\begin{array}{c}\text { IS 12269[8] } \\
\text { specification } \\
\text { for } 53 \text { grade } \\
\text { OPC } \\
\end{array}$ & $\begin{array}{l}\text { Present } \\
\text { study- } \\
\text { OPC 53 } \\
\text { grade } \\
\end{array}$ \\
\hline \multicolumn{2}{|c|}{ Specific gravity } & - & 3.15 \\
\hline \multicolumn{2}{|c|}{ Standard consistency $(\%)$} & _ & $28.0 \%$ \\
\hline \multicolumn{2}{|c|}{ Initial setting time in min } & $>30$ minutes & 110 minutes \\
\hline \multicolumn{2}{|c|}{ Final setting time in $\min$} & $<600$ minutes & 260 minutes \\
\hline \multirow{3}{*}{$\begin{array}{l}\text { Compressive } \\
\text { strength } \\
(\mathrm{MPa})\end{array}$} & 3 days & 27 & 27.5 \\
\hline & 7 days & 37 & 38.08 \\
\hline & $\begin{array}{c}28 \\
\text { days }\end{array}$ & 53 & 54.32 \\
\hline
\end{tabular}

\section{B. Fine Aggregate}

In the present investigation, the river sand available at Chennai was used and the following tests were carried out on the sample as per IS: 2386- 1968 (III):

- Specific gravity and Fineness modulus

The results of tests on sand are listed in the Table 2

Table- II: Properties of Fine Aggregate

\begin{tabular}{|l|l|}
\hline Properties & Results \\
\hline Specific gravity of sand & 2.68 \\
\hline Fineness modulus & 2.73 \\
\hline Sand Conforming & Zone II \\
\hline Bulk density $\left(\mathrm{kg} / \mathrm{m}^{3}\right)$ & 1685 \\
\hline
\end{tabular}

\section{Coarse Aggregate}

In the present investigation, locally available blue granite crushed stone aggregates of size $20 \mathrm{~mm}$ were used and the various tests carried out on the aggregates as per IS: 23861968 (III):

- Specific gravity, Bulk density and Fineness modulus The results of the tests on coarse aggregate are listed in the Table 3.

Table-III: Properties of Coarse Aggregate

\begin{tabular}{|c|c|}
\hline Property & Results \\
\hline Specific gravity & 2.69 \\
\hline Dry Rodded Weight $\left(\mathrm{kg} / \mathrm{m}^{3}\right)$ & 1550.0 \\
\hline Fineness modulus & 7.15 \\
\hline
\end{tabular}

\section{Chemical Admixtures}

In concrete, the water-binder ratio is generally kept as low as possible and hence to obtain the given degree of workability, chemical admixtures, such as, Super plasticizers were used. Poly-carboxylic group based superplastisizer, Structro 100 (a product of Fosroc chemicals), is used throughout the investigation. This group maintains the electrostatic charge on the cement particles and prevents flocculation by adsorption on the surface of cement particles. It is a light yellow colored liquid. The specific gravity of superplastisizer is 1.08-1.14 and solid content is 40 percent by mass.

\section{E. Water}

In the present investigation, potable water was used.

\section{F. Steel Fibers}

The steel fibers purchased from M/s Stewole and Co is used in the present investigation. Steel fiber used was straight and crimped shaped fiber with a total length of $18 \mathrm{~mm}$ and $30 \mathrm{~mm}$ with diameters of $0.45 \mathrm{~mm}$ and aspect ratio of 67 and 40 . The fibers used with the ultimate tensile strength of $800 \mathrm{MPa}$ (from the data supplied by the manufacturers). From the results of the earlier investigations conducted at SERC, a fiber content of 640 $\mathrm{kg} / \mathrm{m}^{3}$ ( $8 \%$ by volume of concrete) for SIFCON and a fiber content of $40 \mathrm{~kg} / \mathrm{m}^{3}, 60 \mathrm{~kg} / \mathrm{m}^{3}$ and $80 \mathrm{~kg} / \mathrm{m}^{3}(0.5 \%, 0.75 \%$ and $1 \%$ by volume of concrete) for SFRC (Steel Fiber Reinforced Concrete) was chosen and kept constant throughout the investigations.

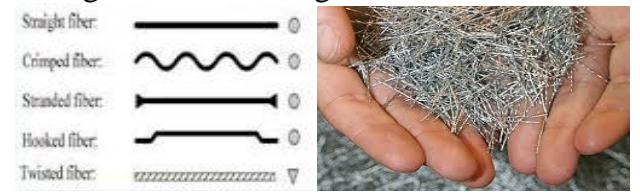

Fig. 1: Types of Steel FiberFig. 2: Crimped Steel Fiber

\section{MIX PROPORTION}

Table- IV: Mix Proportion

\begin{tabular}{|c|c|c|c|c|}
\hline Specimen & $\begin{array}{l}\text { Mix Proportion } \\
\text { (C:S:CA10mm:C }\end{array}$ & Type of & Aspect & Fiber \\
\hline & $\begin{array}{l}\text { A20mm: } \quad \text { w/c: } \\
\text { SP) }\end{array}$ & fiber & ratio & volume \\
\hline $\begin{array}{l}\text { SIFCON } \\
\text { S1 }\end{array}$ & $\begin{array}{l}1: 1: 0: 0: 0.35: \\
0.13 \%\end{array}$ & Straight & 67 & $8 \%$ \\
\hline $\begin{array}{l}\text { SIFCON } \\
\text { S2 }\end{array}$ & $\begin{array}{l}1: 1: 0: 0: 0.35: \\
0.13 \%\end{array}$ & Straight & 40 & $8 \%$ \\
\hline $\begin{array}{l}\text { SIFCON } \\
\mathrm{C} 1\end{array}$ & $\begin{array}{l}1: 1: 0: 0: 0.35: \\
0.13 \%\end{array}$ & Crimped & 67 & $8 \%$ \\
\hline $\begin{array}{l}\text { SIFCON } \\
\mathrm{C} 2\end{array}$ & $\begin{array}{l}1: 1: 0: 0: 0.35: \\
0.13 \%\end{array}$ & Crimped & 40 & $8 \%$ \\
\hline $\begin{array}{l}\text { SFRC S1- } \\
1\end{array}$ & $\begin{array}{l}1: 1.86: 1.26 \\
1.26: 0.4: 0.2 \%\end{array}$ & Straight & 67 & $0.5 \%$ \\
\hline $\begin{array}{l}\text { SFRC S1- } \\
2\end{array}$ & $\begin{array}{l}1: 1.86: 1.26 \\
1.26: 0.4: 0.2 \%\end{array}$ & Straight & 67 & $0.75 \%$ \\
\hline $\begin{array}{l}\text { SFRC S1- } \\
3\end{array}$ & $\begin{array}{l}1: 1.86: 1.26 \\
1.26: 0.4: 0.2 \%\end{array}$ & Straight & 67 & $1 \%$ \\
\hline $\begin{array}{l}\text { SFRC S2- } \\
1\end{array}$ & $\begin{array}{l}1: 1.86: 1.26 \\
1.26: 0.4: 0.2 \%\end{array}$ & Straight & 40 & $0.5 \%$ \\
\hline $\begin{array}{l}\text { SFRC S2- } \\
2\end{array}$ & $\begin{array}{l}1: 1.86: 1.26 \\
1.26: 0.4: 0.2 \%\end{array}$ & Straight & 40 & $0.75 \%$ \\
\hline $\begin{array}{l}\text { SFRC S2- } \\
3\end{array}$ & $\begin{array}{l}1: 1.86: 1.26 \\
1.26: 0.4: 0.2 \%\end{array}$ & Straight & 40 & $1 \%$ \\
\hline $\begin{array}{l}\text { SFRC } \\
\text { C1-1 }\end{array}$ & $\begin{array}{l}1: 1.86: 1.26 \\
1.26: 0.4: 0.2 \%\end{array}$ & Crimped & 67 & $0.5 \%$ \\
\hline $\begin{array}{l}\text { SFRC } \\
\text { C1-2 }\end{array}$ & $\begin{array}{l}1: 1.86: 1.26 \\
1.26: 0.4: 0.2 \%\end{array}$ & Crimped & 67 & $0.75 \%$ \\
\hline $\begin{array}{l}\text { SFRC } \\
\text { C1-3 }\end{array}$ & $\begin{array}{l}1: 1.86: 1.26: \\
1.26: 0.4: 0.2 \%\end{array}$ & Crimped & 67 & $1 \%$ \\
\hline $\begin{array}{l}\text { SFRC } \\
\text { C2-1 }\end{array}$ & $\begin{array}{l}1: 1.86: 1.26: \\
1.26: 0.4: 0.2 \%\end{array}$ & Crimped & 40 & $0.5 \%$ \\
\hline $\begin{array}{l}\text { SFRC } \\
\text { C2-2 }\end{array}$ & $\begin{array}{l}1: 1.86: 1.26 \\
1.26: 0.4: 0.2 \%\end{array}$ & Crimped & 40 & $0.75 \%$ \\
\hline $\begin{array}{l}\text { SFRC } \\
\text { C2-3 }\end{array}$ & $\begin{array}{l}1: 1.86: 1.26 \\
1.26: 0.4: 0.2 \%\end{array}$ & Crimped & 40 & $1 \%$ \\
\hline Control & $\begin{array}{l}1: 1.86: 1.26 \\
1.26: 0.4: 0.2 \%\end{array}$ & No & No & No \\
\hline
\end{tabular}

The mix design is made as per ACI 211 method for M30 Grade.

\section{RESULT AND DISCUSSION}

\section{A. Compressive Strength}


The behaviour of SIFCON, Steel Fiber Reinforced Concretes (SFRC) and conventional concrete of M30 grade were tested under compression. Compressive strength test at 28 days were carried out and the results are given below. The fiber content used in this investigation are $640 \mathrm{Kg} / \mathrm{m}^{3}$ for SIFCON and $40 \mathrm{Kg} / \mathrm{m}^{3}, 60 \mathrm{Kg} / \mathrm{m}^{3}$, and $80 \mathrm{Kg} / \mathrm{m}^{3}$ for SFRC of concrete. The cube size used for testing is 100x100x100mm cube, the test results are given below. Figure 3 and 4 shows the percentage increase in compressive strength for different fibers.From the results obtained the following inferences can be made,

- The compressive strength of SIFCON gets increased by more than 1.5 times than SFRC and control

- The compressive strength of SFRC increase/decrease with as the fiber volume increases from $0.5 \%$ to $1 \%$ depending on the fiber distribution.

- In SFRC, with different aspect ratio there is no change in compressive strength.

- In SIFCON, with different aspect ratio there is a change in compressive strength.

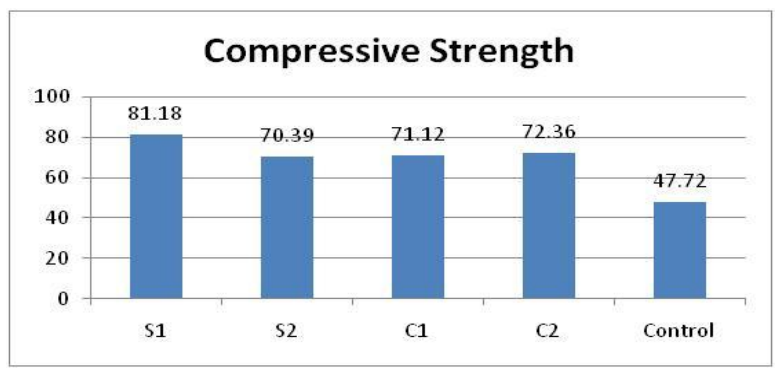

Fig. 3: Compressive Strength of SIFCON and Control Concrete

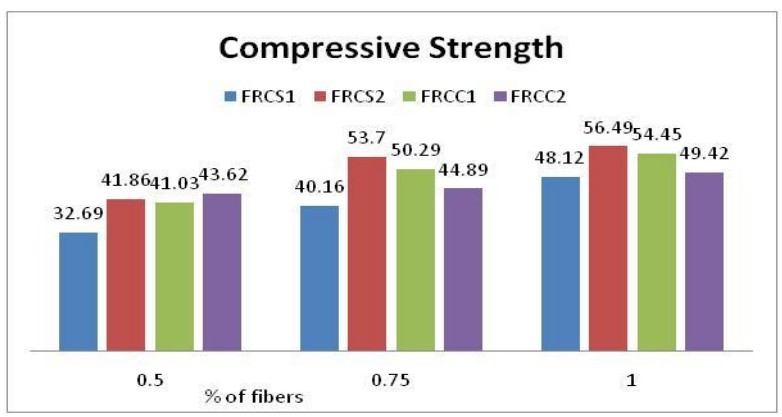

Fig. 4: Compressive Strength of SFRC

\section{B. Split Tensile Strength}

The behaviour of SIFCON, Steel Fiber Reinforced Concretes (SFRC) and conventional concrete of M30 grade were tested under compression. Split tensile strength test at 28 days were carried out and the results are given below. The cylinder size used for testing is $100 \mathrm{~mm} \times 200 \mathrm{~mm}$, the test results are given below. Figure 5 and 6 shows the percentage increase in split tensile strength for different fibers. From the results obtained the following inferences can be made,

- Split tensile strength SIFCON gets increased by more than 3 times than SFRC and control concrete.

- In SIFCON when aspect ratio is varied the split tensile strength gets increased by 1.25 times.

- In SFRC there is no change in split tensile strength with different aspect ratio.

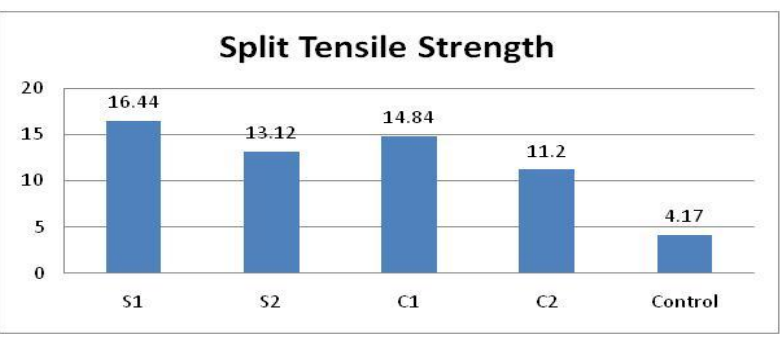

Fig. 5: Split Tensile Strength of SIFCON and Control Concrete

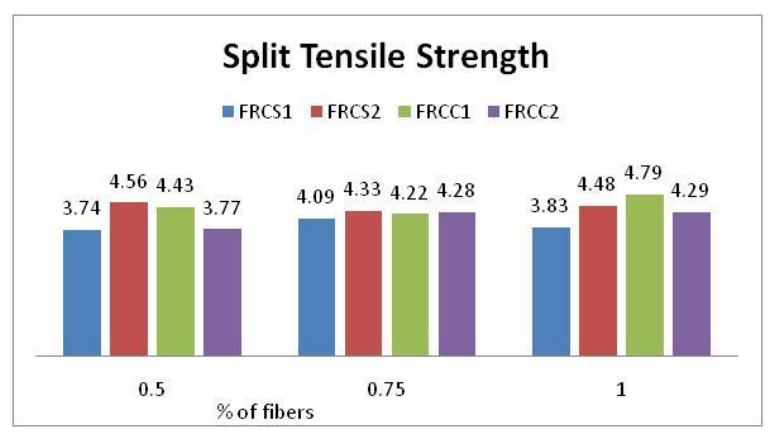

Fig.6: Split Tensile Strength of SFRC

\section{Flexural Strength}

The flexural test method followed was based on test method given in ASTM C 78-94. Mould size used was $100 \mathrm{x}$ $100 \times 400 \mathrm{~mm}$ prism. Four point loading is used for test. Force applied to the beam will be perpendicular to the face of the specimen and applied without eccentricity. Ratio of distance between point of applied load and nearest reaction to the depth of the beam shall not be less than one. Flexural strength test was carried out for 28 days. The test results are given below, Figure 7 and 8 shows the percentage increase in flexural strength for different fibers

From the results obtained the following inferences can be made,

- Flexural strength of SIFCON gets increased by more than 3.5 times than SFRC and control concrete

- In SIFCON when aspect ratio is varied the flexural strength gets increased by 1.8 times

- In SFRC when aspect ratio is varied the flexural strength gets increased by 1.2 times

- There is no change in the flexural strength when fiber volume is varied

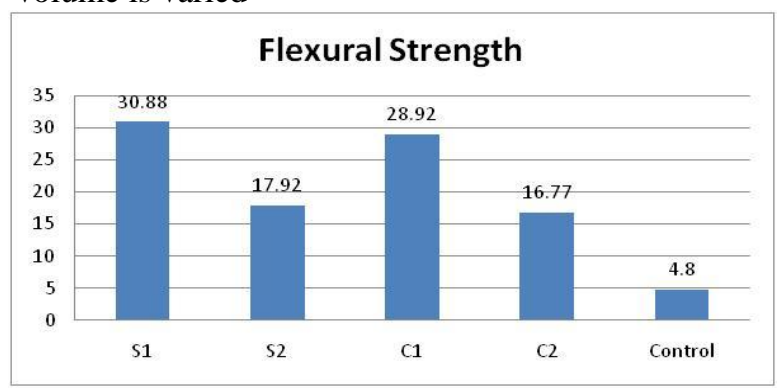

Fig. 7: Flexural Strength of SIFCON and Control Concrete 


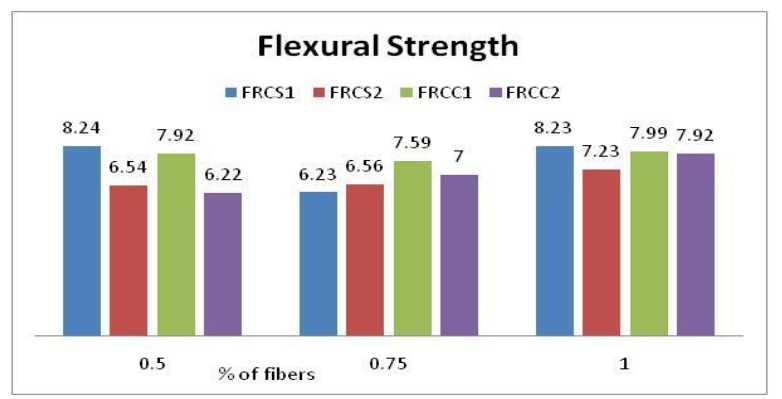

Fig. 8: Flexural Strength of SFRC

\section{CONCLUSION}

Based on the experimental study the following conclusions can be drawn

- The fiber content is increased then the compressive strength of SFRC is also increased. The influence of aspect ratio is negligible in compressive strength. However, for SIFCON specimen the compressive strength depends on the aspect ratio, this is because the fiber content is kept constant which lead to the change in number of fibers per unit volume.

- Split tensile strength of SIFCON increased by 3 to 4 times than SFRC and control concrete.

- Flexural strength of SIFCON increased by 3 to 5 times than that of SFRC and 7 times than that of control concrete

\section{REFERENCES}

1. Balaguru, P., And Kendzulak, J., (1987). "Mechanical Properties Of Slurry Infiltrated Fiber Concrete (Sifcon)." Fiber Reinforced Concrete - Properties And Applications, ACI SP-105. American Concrete Institute, Detroit. Pp. 247-268.

2. Homrich, J. R., And Naaman, A. E. (1987). "Stress-Strain Properties Of Sifcon In Compression." Fiber Reinforced Concrete - Properties And Applications. Aci Sp-105., American Concrete Institute. Detroit, Michigan. Pp. 283-304.

3. K.A. Marchand, P.T. Nash And P.A. Cox.,(1988) "Tests And Analysis Of The Localized Response Of Slurry Infiltrated Fiber Concrete (Sifcon) And Conventional Reinforced Concrete (Crc) Subjected To Blast And Fragment Loading", Journal De Physique Colloque C 3 , Supplement Au N09, Tome 49, September 1988

4. Antonio Nanni., (1990) "Properties Of Aramid-Fiber Reinforced Concrete And Sifcon" Asce Structure Congress, Session 69, Baltimore, Maryland.

5. Neamkumar Banthia And Ashish Dubey. (1999) "Measurement Of Flexural Toughness Of Fiber Reinforced Concrete Using A Novel Technique - Part 1: Assessment And Calibration". Aci Materials Journal. Vol. 96, No.6, Pp 651-656.

6. Neamkumar Banthia And Ashish Dubey. (2000) "Measurement Of Flexural Toughness Of Fiber Reinforced Concrete Using A Novel Technique - Part 2: Performance Of Various Composites". ACI Materials Journal. Vol. 97, No.1, Pp 3-11.

7. An Yan, Keru Wu, Xiong Zhang., (2002) “A Quantitative Study On The Surface Crack Pattern Of Concrete With High Content Of Steel Fiber", Cement And Concrete Research 32, 1371-1375

8. Hilmi Coskun.,( 2003) "The Effects Of Construction Practices On The Slurry Infiltrated Mat Concrete (Simcon) Strengthened R-C Column", Fifth National Conference On Earthquake Engineering, 26-30 May 2003, Istanbul, Turkey

9. Thamilselvi. P. And Devadoss Manoharan. P., (2003) "Study Of Behaviour Of Reinforced Concrete Frames With Slab Using Sifcon In Beam Column Joints"

10. Raghu Prasad P.S., Ravindranatha., And Keshaw Jee Sharma., (2003) "Experimental Investigation On Flexural Strength Of Slurry Infiltrated Fiber Concrete(Sifcon)", Proceeding Of The Incontest 2003, September 2003
11. Halit Yazici , Huseyin Yigiter, Serdar Aydin, Bulent Baradan., (2006) "Autoclaved SIFCON With High Volume Class C Fly Ash Binder Phase", Cement And Concrete Research 36, 481 - 486

12. Ziad Bayasi And Jack Zeng., (2007) "Flexural Behavior Of Slurry Infiltrated Mat Concrete (Simcon)", Journal Of Materials In Civil Engineering, November 2007

13. Dr. H. K.Sharma , V.P. Singh And Mukesh Kumar.,( 2008) "Structural Optimization And Performance Of Sifcon Plates", 7th Wseas Int. Conf. On Applied Computer \& Applied Computational Science (Acacos '08), Hang Zhou, China, April 6-8, 2008

14. ABDOU, H. M., (1990) "Precast Construction using Slurry Infiltrated Fiber Concrete Joints under Load Reversals", Ph. D. Thesis, University of Michigan. 1990.

15. P.N.BALAGURU and S.P.SHAH, (1992) "Fiber- Reinforced Cemen Composites" McGraw-Hill, Inc, - 1992

16. D.J.STEVENS, ET, AL, (1995) "Testing of Fiber Reinforced Concrete". ACI SP-155.

17. BRYAN THANE WOOD.,( 2000) "Use of Slurry Infiltrated Fiber Concrete in Hinge Regions of Earthquake Resistant Structures", Ph.D Thesis, North Carolina State University. 2000

18. BIS: 2386 - 1963 (I to IV) "Methods of test for aggregates for concrete."

19. BIS: 4031- 1988 "Methods of physical tests for Hydraulic cement".

20. BIS: 5816- 1999 "Splitting tensile strength of concrete - Method of tests".

21. BIS: 12269 - 1987 "Specification for 53 grade Ordinary Portland Cement."

22. ACI 544 - Measurement of properties of Fiber Reinforced Concrete'

23. ASTM C 78-94 - Standard Test for Flexural Strength of Concrete (using Simple Beam with Four-point Loading)

\section{AUTHORS PROFILE}

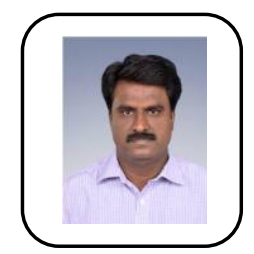

Dr.Muthukannan M completed his Ph.D in Civil Engineering in Anna University, Chennai in the year 2010. He completed Master of Engineering in the field of Transportation Engineering and Management in College of Engineering, Guindy, Chennai in the year 2004. He completed his Bachelor of Engineering under Madurai Kamarajar University in the year 2000. He is presently working as a Professor in Civil Engineering department at Kalasalingam University, Tamilnadu, India. He is guiding for many $\mathrm{Ph} . \mathrm{D}$ scholars in the field of transporation engineering and Geopolymer Technology. He has published various quality papers in the reputed journals. His main thrust research areas are Geopolymer technology, transportation network design, transport management and travel demand management.

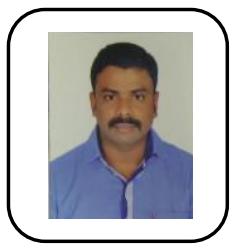

Mr. Suresh Kumar.A is doing full time PhD in Department of Civil Engineering from Kalasalingam Academy of Research and Education, Krishnankoil, India. He completed his Bachelor degree in Civil Engineering from Raja College of Engineering and Technology, affiliated to Anna University, Chennai. He completed his Master in Engineering in Structural Engineering fromMepcoSchlenk Engineering College affiliated to Anna University, Thirunelveli. His areas of interest are Concrete Technology, alternative construction materials, eco-friendly materials and Prestressed Concrete. 